\title{
PERTANGGUNGJAWABAN PIDANA ATAS TINDAKAN DISKRESI PEJABAT PEMERINTAHAN YANG BERINDIKASI ADANYA PENYALAHGUNAAN WEWENANG
}

\author{
Sabarudin Hulu, Pujiyono \\ Program Studi Magister Ilmu Hukum, Fakultas Hukum Universitas Diponegoro \\ Jalan Imam Bardjo, Pleburan, Semarang \\ hulunias@yahoo.com
}

\begin{abstract}
This study aims to determine how the accountability of government officials on discretion acts indicating the abuse of authority and how the benchmarks of discretion measures by government officials can be categorized as abuse of authority that must be criminally accounted for. This research uses normative juridical approach method. Discretion taken by government officials and ignore the provisions of applicable legislation, is very vulnerable to abuse of authority that leads to the act of corruption. Government officials issue discretions by taking refuge in law No. 30 of 2014 on Government Administration, arguing that there are issues to be resolved whilst legislation provides choice, non-regulation, incomplete or unclear, and/or government stagnation.
\end{abstract}

Keywords: Public Service, Discretion, Corruption

\begin{abstract}
Abstrak
Penelitian ini bertujuan untuk mengetahui bagaimana pertanggungjawaban pejabat pemerintahan atas tindakan diskresi yang berindikasi adanya penyalahgunaan wewenang serta bagaimana tolok ukur tindakan diskresi oleh pejabat pemerintahan dapat dikategorikan sebagai penyalahgunaan wewenang sehingga harus dipertanggungjawabkan secara pidana. Penelitian ini menggunakan metode pendekatan yuridis normatif. Diskresi yang diambil pejabat pemerintahan dan mengabaikan ketentuan peraturan perundang-undangan yang berlaku, sangat rentan terjadi penyalahgunaan wewenang yang mengarah pada perbuatan tindak pidana korupsi. Pejabat pemerintahan menerbitkan diskresi dengan berlindung pada Undang-Undang No. 30 Tahun 2014 tentang Administrasi Pemerintahan, dengan alasan karena ada persoalan yang harus diselesaikan sementara peraturan perundang-undangan memberikan pilihan, tidak mengatur, tidak lengkap atau tidakjelas, dan/atau adanya stagnasi pemerintahan.
\end{abstract}

Kata Kunci: Pelayanan Publik, Diskresi, Korupsi.

\section{A. Pendahuluan}

Tujuan Negara Indonesia tercantum dalam alinea keempat pembukaan UndangUndang Dasar Negara Republik Indonesia Tahun 1945 yakni "melindungi segenap bangsa Indonesia dan seluruh tumpah darah Indonesia dan untuk memajukan kesejahteraan umum, mencerdaskan kehidupan bangsa, dan ikut melaksanakan ketertiban dunia yang berdasarkan kemerdekaan, perdamaian abadi dan keadilan sosial". Tindakan penyelenggara negara dan pemerintahan yang korupsi, akan menghambat pencapaian tujuan negara. Kondisi korupsi ini berkembang hingga menembus semua lini pemerintahan baik dari pusat hingga ke daerah. Akibat korupsi, tidak hanya merugikan perekonomian negara tetapi juga merusak perekonomian rakyat, dan menjadi ancaman serius bagi stabilitas ekonomi nasional dan ketahanan nasional (Wijayanto, 2009, p. 569).

Menguatnya tuntutan rakyat terhadap negara untuk berperan aktif dalam 
mewujudkan tujuan negara sebagaimana tercantum pada alinea keempat pembukaan UUD 1945, mengakibatkan negara tidak hanya sebagai penjaga keamanan dan ketertiban (law and order). Negara senantiasa diharapkan hadir untuk semua aspek kehidupan rakyat. Konsep negara kesejahteraan (welfare state), peranan negara memiliki fungsi pengaturan, pelayanan, pembangunan, pemberdayaan, dan perlindungan. Kondisi tersebut sangat memungkinkan karena aparatur berada pada posisi sebagai perumus dan penentu daya kebijakan, serta sebagai pelaksana dari segala peraturan, melalui hierarki yang lebih tinggi sampai pada hierarki yang terendah (Sinambela, 2008, p. 34).

Dalam mewujudkan tujuan pembangunan nasional diperlukan kewenangan pejabat pemerintahan yang luas, nyata dan bertanggungjawab untuk melayani kepentingan masyarakat berdasarkan prinsip kemanfaatan, keadilan, keterbukaan, dan partisipasi serta pertanggungjawaban kepada masyarakat. Kewenangan pejabat pemerintahan harus berhadapan dengan kenyataan, meluasnya aspek kehidupan sosial dan kesejahteraan masyarakat pada umumnya, yang mengakibatkan administrasi negara tidak boleh menolak untuk mengambil keputusan dengan alasan ketiadaan peraturan. Keleluasaan pejabat pemerintahan bergerak, diberikan kebebasan bertindak yang disebut diskresi.

Idealnya, setiap permasalahan yang dihadapi dan tindakan ataupun keputusan yang diambil oleh seorang pejabat pemerintahan dalam menjalankan fungsinya, dilandasi dengan peraturan perundangundangan dan asas-asas umum pemerintahan yang baik. Peraturan perundang-undangan tidak dapat mengatur semua kepentingan dan dinamika yang terjadi di masyarakat. Pejabat pemerintahan dalam melayani masyarakat, diperlukan inisiatif sendiri dan memerlukan kemerdekaan untuk bertindak. Pejabat administrasi negara dalam melaksanakan tugas-tugas penyelenggaraan kepentingan umum tidak hanya didasarkan ada tidaknya suatu aturan(Patiro, 2012, p. 3).

Peranan penegak hukum dan lembaga negara sebagai lembaga pengawasan terhadap keputusan dan tindakan pejabat pemerintahan merupakan fungsi kontrol dalam mencegah tindakan yang menyimpang. Sejarah pemikiran manusia mengenai politik dan hukum secara bertahap menuju kearah kesimpulan bahwa negara merupakan negara yang akan mewujudkan harapan para warga negara akan kehidupan yang tertib, adil, dan sejahtera jika negara itu diselenggarakan berdasarkan hukum sebagai aturan (Kusumohamidjojo, 1999, p. 147).

Pembatasan tindakan pejabat pemerintahan, maka peranan, tugas, dan wewenang juga terbatas, yang akhirnya membawa konsekuensi bahwa pejabat pemerintah tidak memiliki diskresi. Negara hukum bertujuan untuk melindungi hak asasi warga negaranya dengan cara membatasi dan mengawasi gerak langkah dan kekuasaan negara dengan undang-undang (Azhary, 1995, p. 75).

Kebebasan penyelenggara pemerintahan diperlukan dalam mengambil keputusan untuk segera bertindak memujudkan rakyat yang sejahtera. Kebebasan ini sering disebut dengan diskresi. Pemberian kewenangan kepada pejabat pemerintahan untuk bertindak atas inisiatif sendiri dikenal dengan istilah freies ermesen/ discreationary power, dalam bahasa Indonesia dikenal dengan istilah diskresi, yaitu suatu istilah yang didalamnya mengandung kewajiban dan kekuasaan yang luas(Patiro, 2012, p. 2).

Keragu-raguan pejabat pemerintahan dalam mengambil keputusan dan atau bertindak dalam mewujudkan kesejahteraan dan kemakmuran bangsa dan negara, kemudian Pemerintah bersama Dewan Perwakilan Rakyat Republik Indonesia memutuskan dan menetapkan UndangUndang Nomor 30 Tahun 2014 tentang Administrasi Pemerintahan, yang didalamnya mengatur mengenai diskresi pejabat pemerintahan.

Dalam penelitian ini, penulis memfokuskan untuk mengetahui, mengkaji dan meneliti permasalahan: bagaimana pertanggungjawaban pejabat pemerintahan atas tindakan diskresi yang berindikasi adanya penyalahgunaan wewenang serta bagaimana tolok ukur tindakan diskresi oleh pejabat pemerintahan dapat dikategorikan 
sebagai penyalahgunaan wewenang sehingga harus dipertanggungjawabkan secara pidana.

\section{B. Metode Penelitian}

Penelitian ini menggunakan pendekatan yang bersifat yuridis normatif, yakni dengan cara menelaah dan menginterprestasikan halhal yang bersifat teori terkait asas atau teoriteori, konsepsi, dan norma hukum yang berkaitan dengan pertanggungjawaban pidana atas tindakan diskresi pejabat pemerintahan yang berindikasi terjadinya penyalahgunaan wewenang. Metode literatur melalui buku, peraturan perundangundangan, putusan hakim, dan dokumen lainnya yang relevan dan ada hubungannya dengan penelitian ini adalah sangat penting.

\section{Hasil dan Pembahasan}

1. Tanggung Jawab Hukum Dalam Penggunaan Diskresi Atau Kebijakan

Pengaturan diskresi pejabat pemerintahan dalam Undang-Undang Nomor 30 Tahun 2014 tentang Administrasi Pemerintahan, dimaksudkan tidak hanya sebagai payung hukum bagi penyelenggaraan pemerintahan, tetapi juga sebagai instrumen hukum untuk meningkatkan kualitas pelayanan pemerintahan kepada masyarakat, dan dapat mewujudkan pemerintahan yang baik bagi semua badan atau pejabat pemerintahan di pusat maupun di daerah. Pelayanan pemerintahan sebagaimana diatur dalam Pasal 1 butir (1) Undang-Undang Nomor 25 Tahun 2009 tentang Pelayanan Publik menyebutkan bahwa pelayanan publik adalah kegiatan atau rangkaian kegiatan dalam rangka pemenuhan kebutuhan pelayanan sesuai dengan peraturan perundang-undangan bagi setiap warga negara dan penduduk atas barang, jasa dan/atau pelayanan administratif yang disediakan oleh penyelenggara pelayanan publik.

Penyelenggara pelayanan publik dalam bertindak diwajibkan berdasarkan peraturan perundang-undangan yang berlaku. Aturan ini membatasi keleluasaan pejabat pemerintahan dalam mewujudkan pelayanan publik. Tindakan diskresi pejabat pemerintahan merupakan instrumen yang dapat menyelesaikan persoalan dalam bertindak untuk melakukan inovasi pelayanan publik, dengan ruang lingkup dan batasan diskresi yang telah diatur dalam peraturan perundang-undangan.

Diskresi pejabat pemerintahan telah diatur dalam Pasal 1 angka (9) UndangUndang Republik Indonesia Nomor 30 Tahun 2014 tentang Administrasi Pemerintahan, menyebutkan diskresi adalah keputusan dan/atau tindakan yang ditetapkan dan/atau dilakukan oleh pejabat pemerintahan untuk mengatasi persoalan konkret yang dihadapi dalam penyelenggaraan pemerintahan dalam hal peraturan perundang-undangan yang memberikan pilihan, tidak mengatur, tidak lengkap atau tidak jelas, dan/atau adanya stagnasi pemerintahan.

Ruang lingkup diskresi diatur dalam Pasal 23 Undang-Undang Nomor 30 Tahun 2014 tentang Administrasi Pemerintahan menyatakan Diskresi Pejabat Pemerintahan meliputi:

a. Pengambilan keputusan dan/atau tindakan berdasarkan ketentuan peraturan perundang-undangan yang memberikan suatu pilihan keputusan dan/atau tindakan.

b. Pengambilan keputusan dan/atau tindakan karena peraturan perundangundangan tidak mengatur;

c. Pengambilan keputusan dan/atau tindakan karena peraturan perundangundangan tidak lengkap atau tidak jelas; dan

d. Pengambilan keputusan dan/atau tindakan karena adanya stagnasi pemerintahan guna kepentingan yang lebih luas.

Pengaturan diskresi dalam UndangUndang Nomor 30 Tahun 2014 tentang Administrasi Pemerintahan, masih belum terinci sehingga memunculkan penafsiran yang berbeda. Prosedur atasan pejabat dalam melakukan penolakan dan penetapan persetujuan diskresi. Belum diatur secara jelas terkait pengajuan diskresi kepada atasan pejabat namun tidak memberikan jawaban dalam waktu 5 (lima) hari sejak permohonan diskresi diterima. Pengaturan waktu 5 (lima) hari untuk mengajukan permohonan persetujuan terlebih dahulu kepada atasan pejabat, hal ini menghambat pelayanan publik khususnya kebutuhan yang mendesak, 
keadaan darurat, dan/atau terjadi bencana alam. Menurut penulis, tidak dilakukan pengaturan waktu mengenai permohonan persetujuan dari atasan pejabat tetapi cukup dengan laporan pertanggung-jawaban pelaksanaan diskresi yang dilaksanakan dengan itikad baik.

\section{Tanggung Jawab Hukum atas Penyalahgunaan Wewenang atas Diskresi}

Tanggung jawab pejabat pemerintahan dalam melaksanakan fungsinya dibedakan antara tanggung jawab pribadi dan tanggung jawab jabatan. Menurut Philipus M. Hadjon (Hadjon, 1997, p. 1), bahwa tanggung jawab jabatan berkenaan dengan legalitas (keabsahan) tindakan pemerintah. Dalam hukum administrasi, persoalan legalitas tindakan pemerintahan berkaitan dengan pendekatan terhadap kekuasaan pemerintahan. Sedangkan tanggung jawab pribadi berkaitan dengan pendekatan fungsionaris atau perilaku dalam hukum administrasi. Tanggung jawab pribadi berkenaan dengan maladministrasi dalam penggunaan wewenang maupun pelayanan publik.

Pembedaan antara tanggung jawab jabatan dan tanggung jawab pribadi atas tindakan pemerintahan membawa konsekuensi berkaitan dengan tanggung jawab pidana, tanggung gugat perdata, dan tanggung gugat tata usaha negara. Tanggung jawab pidana adalah tanggung jawab pribadi. Kaitannya dengan tindakan pemerintahan, tanggung jawab pribadi seorang pejabat berhubungan dengan adanya perbuatan maladministrasi. Tanggung gugat perdata dapat menjadi tanggung gugat jabatan berkaitan dengan perbuatan melanggar hukum oleh penguasa. Tanggung gugat perdata menjadi tanggung gugat pribadi apabila terdapat perbuatan maladministrasi. Tanggung gugat Tata Usaha pada dasarnya adalah tanggung gugat jabatan.

Diskresi sebagai wewenang pejabat pemerintahan merupakan wewenang bebas yang dimiliki oleh pejabat pemerintahan sebagai lawan dari wewenang terikat (gebonden bevoegdheid). Sifat dan karakter pejabat pemerintahan mengharuskan kekuasaan pemerintah tidak sekedar melaksanakan undang-undang (wetmatigheid van bestuur), tetapi harus mengedepankan penetapan tujuan (doelstelling) dan kebijakan (beleid).

Tindakan pejabat pemerintahan yang mengedepankan tujuan (doelstelling) dan kebijakan (beleid) merupakan kekuasaan yang aktif. Tindakan aktif ini menurut Philipus M. Hadjon dalam konsep hukum administrasi secara intrinsik merupakan unsur-unsur utama dari "sturen" (besturen) (Widyaningtyas, n.d.). Dalam konsep bestuur kekuasaan pemerintahan dalam pelaksanaan wewenang pemerintahan tidaklah sematamata sebagai suatu wewenang yang terikat sebagaimana diatur dalam aturan hukum, tetapi juga merupakan suatu wewenang bebas atau diskresi.

Menurut penulis, diskresi merupakan hak pejabat pemerintahan melalui wewenangnya dalam melakukan tindakan pelayanan publik, bukan merupakan tindakan mengesampingkan peraturan perundangundangan yang berlaku. Kewenangan pemerintahan yang selanjutnya disebut kewenangan adalah kekuasaan Badan dan/atau Pejabat Pemerintahan atau penyelenggara negara lainnya untuk bertindak dalam ranah hukum publik sebagaimana diatur dalam Pasal 1 butir 6 Undang-Undang Nomor 30 Tahun 2014 tentang Administrasi Pemerintahan.

\section{Kewenangan Aparat Penegak Hukum dalam Penanganan Tindak Pidana korupsi Akibat Diskresi yang Berindikasi Terjadi Penyalahgunaan Wewenang}

Aparat penegak hukum memiliki wewenang dalam mencegah dan memberantas korupsi sesuai kewenangan yang diatur dalam peraturan perundangundangan yang berlaku. Komitmen pemerintah untuk memberantas korupsi, dengan mengeluarkan Peraturan Presidan Nomor 87 Tahun 2016 tentang Tim Satuan Bersih Pungutan Liar (Saber Pungli).

Kewenangan aparat penegak hukum dalam melakukan Operasi Tangkap Tangan, tidak hanya pada kasus kecil seperti pungutan liar atau permintaan sejumlah uang yang tidak resmi pada instansi pemerintahan daerah, juga Operasi Tangkap Tangan terhadap pejabat 
pemerintahan yang diduga melakukan korupsi atas penyalahgunaan wewenang. Berbagai tanggapan yang beragam atas penanganan kasus korupsi karena penyalahgunaan wewenang dalam menggunakan diskresi yang menimbulkan kerugian negara. Bahkan, beberapa pejabat pemerintahan mengungkapkan tidak dapat melakukan penyerapan anggaran maksimal karena takut dikiriminalisasi oleh penegak hukum.

Ketentuan Undang-Undang Nomor 30 Tahun 2014 tentang Administrasi Pemerintahan tersebut telah menimbulkan pro dan kontra diantara para ahli hukum, khususnya ahli Hukum Pidana dan ahli Hukum Administrasi Negara berkenaan dengan keberlakuan ketentuan dimaksud dan pengaruhnya terhadap kewenangan Peradilan Tipikor(Sahlan, 2016). Guntur Hamzah, Guru Besar Hukum Administrasi Universitas Hasanuddin, menyatakan keberadaan Undang-Undang Administrasi Pemerintahan akan memperkuat dan menambah daya dobrak upaya pemberantasan korupsi karena dengan adanya APIP, adanya dugaan penyalahgunaan wewenang dapat dideteksi sejak dini sebagai upaya preventif (pencegahan).

Pendapat berbeda disampaikan oleh Krisna Harahap, Hakim Ad Hoc Tipikor di tingkat Mahkamah Agung (MA) yang secara tegas menyatakan bahwa UndangUndangAdministrasi Pemerintahan menghambat upaya pemberantasan tindak pidana korupsi karena ketentuan-ketentuan yang tertuang dalam Undang-Undang Nomor 30 Tahun 2014 (Ari, 2015), nyata-nyata tidak selaras dengan Undang-Undang Nomor 20 Tahun 2001 tentang perubahan atas UndangUndang Nomor 31 Tahun 1999 tentang Pemberantasan Tindak Pidana Korupsi. Ketentuan Pasal 3 Undang-Undang Tipikor yang mengatur bagaimana 'setiap orang yang menyalahgunakan kewenangan, kesempatan atau sarana yang ada padanya karena jabatan atau kedudukan yang dapat merugikan keuangan negara atau perekonomian Negara'. Setiap orang yang memenuhi unsur-unsur delik yang diatur dalam Pasal 3 (bukan hanya Pegawai Negeri) terancam pidana penjara 1-20 tahun, Undang-
Undang Nomor 30 Tahun 2014 menghambat upaya pemberantasan korupsi.

Penulis berpendapat bahwa Undang-Undang Nomor 30 Tahun 2014 tentang Administrasi Pemerintahan, perlindungan hukum serta memberikan batasan dan unsur-unsur terhadap diskresi yang berindikasi terjadi penyalahgunaan wewenang yang mengakibatkan terjadinya perbuatan korupsi.

\section{Penyalahgunaan Wewenang}

Menurut hukum administrasi negara, setiap pemberian wewenang kepada seorang pejabat selalu disertai dengan tujuan dan maksud diberikannya wewenang itu, sehingga penerapan wewenang itu harus sesuai dengan tujuan maksud diberikannya wewenang. Apabila penggunaan wewenang tidak sesuai dengan tujuan dan maksud pemberian semula wewenang itu maka disebut penyalahgunaan wewenang (Syamsudin, Ilyas, \& Badeoda, 2004, p. 47).

Konsekuensi dari negara hukum, wajib adanya jaminan bagi administrasi negara sebagai alat perlengkapan negara untuk dapat menjalankan pemerintahan dan warga negara memiliki hak dan kewajiban mendapat jaminan perlindungan. Oleh karena itu, kekuasaan pemerintah tidak dapat lepas dari perkembangan asas legalitas yang telah dimulai sejak munculnya konsep negara hukum klasik formelerechtsstaat atau liberale rechtsstaat yaitu wetmatigheid van bestuur artinya pemerintahan menurut undangundang(Facruddin, 2004, p. 44).

Terjadinya penyalahgunaan wewenang perlu diukur dengan membuktikan secara faktual bahwa seorang pejabat telah menggunakan wewenangnya untuk tujuan lain atau tidak(Latif, 2014, p. 35). Harus dapat dibuktikan juga bahwa terjadinya penyalahgunaan wewenang dilakukan secara sadar dengan mengalihkan tujuan yang telah diberikan kepada wewenang itu (bukan karena kealpaan). Pengalihan tujuan tersebut didasarkan atas interest pribadi, baik untuk kepentingan dirinya sendiri ataupun untuk orang lain.

Secara yuridis, penyalahgunaan wewenang dalam Undang-Undang Nomor 30 Tahun 2014 tentang Administrasi Pemerintahan dinyatakan terjadi ketika 
"badan dan/atau pejabat pemerintahan dalam membuat keputusan dan/atau melakukan tindakan melampaui wewenang, mencampuradukkan wewenang, dan/atau bertindak sewenang-wenang". Badan dan/atau Pejabat Pemerintahan melampaui wewenang ketika keputusan dan/atau tindakan yang dilakukan dengan:

a) melampaui masa jabatan atau batas waktu berlakunya wewenang;

b) melampaui batas wilayah berlakunya wewenang; dan/atau

c) bertentangan dengan ketentuan peraturan perundang-undangan.

Sedangkan keputusan dan/atau tindakan Badan dan/atau Pejabat Pemerintahan dikategorikan mencampur-adukkan wewenang apabila dilakukan di luar cakupan bidang atau materi wewenang yang diberikan dan/atau bertentangan dengan tujuan wewenang yang diberikan. Badan dan/atau Pejabat Pemerintahan dinyatakan sewenangwenang manakala keputusan dan/atau tindakannya dilakukan tanpa dasar kewenangan dan/atau bertentangan dengan Putusan Pengadilan yang berkekuatan hukum tetap.

Penyelenggara negara dan penyelenggara pemerintah dan dapat dinyatakan melakukan maladministrasi apabila melakukan perbuatan melawan hukum, melampaui wewenang, menggunakan wewenang untuk tujuan lain dari yang menjadi tujuan wewenang tersebut, termasuk kelalaian atau pengabaian kewajiban hukum dalam penyelenggaraan pelayanan publik yang menimbulkan kerugiaan materiil dan/ atau immateriil bagi masyarakat dan orang perseorangan, sesuai Pasal 1 butir 3 UndangUndang Nomor 37 Tahun 2008 tentang Ombudsman Republik Indonesia.

Penyalahgunaan wewenang dalam Undang-Undang Administrasi Pemerintahan tidak menjelaskan definisi, pengertian, maupun konsep penyalahgunaan wewenang. Pasal 17 Undang-Undang Nomor 30 Tahun 2014 tentang Administrasi Pemerintahan hanya mengatur tentang larangan penyalahgunaan wewenang dan tiga spesies larangan penyalahgunaan wewenang, yang meliputi larangan melampaui wewenang, larangan mencampur-adukkan wewenang dan larangan bertindak sewenang-wenang, yang secara konseptual dan teoritis menurut ahli Hukum Administrasi Negara dan praktisi Hukum Administrasi Negara (hakim PTUN) tidak tepat dan cenderung menyesatkan -(Hadjon, 2015, pp. 5860).

\section{Menyalahgunakan Kewenangan}

Menyalahgunakan kewenangan dalam konteks ini berkaitan dengan jabatan pejabat publik, bukan dalam kaitan dan pemahaman jabatan dalam ranah struktur keperdataan. Namun demikian, istilah "menyalahgunakan kewenangan" seperti halnya "penyalahgunaan wewenang" sebenarnya merupakan istilah yang lahir dalam rumpun Hukum Administrasi Negara, bahkan istilah tersebut merupakan salah satu asas dalam AUPB, yaitu asas tidak menyalahgunakan kewenangan.

Unsur "menyalahgunakan kewenangan" dalam Tipikor dapat ditemukan dalam rumusan Pasal 3 Undang-Undang Pemberantasan Tipikor, yang selalu dikaitkan dengan jabatan yang dimiliki seseorang pejabat publik (menyalahgunakan kewenangan karena jabatan), yang rumusannya sebagai berikut: "Setiap orang yang dengan tujuan menguntungkan diri sendiri atau orang lain atau suatu korporasi, menyalahgunakan kewenangan, kesempatan atau sarana yang ada padanya karena jabatan atau kedudukan yang dapat merugikan keuangan negara atau perekonomian negara, dipidana dengan dengan pidana penjara seumur hidup atau pidana penjara paling singkat 1 (satu) tahun dan paling lama 20 (dua puluh) tahun dan atau denda paling sedikit $\mathrm{Rp}$. 50.000.000 (lima puluh juta rupiah) dan paling banyak Rp. 1.000.000.000,00 (satu miliar rupiah).

Dalam Pasal 1 angka (3) UndangUndang Pemberantasan Tipikor, subjek hukum dalam tindak pidana ini adalah setiap orang yang berarti orang perseorangan atau termasuk korporasi. Akan tetapi karena korporasi sebagai rechtsperson tidak mungkin memiliki jabatan atau kedudukan seperti natuurlijke person, maka Tipikor yang terdapat dalam ketentuan Pasal 3 tersebut hanya dapat dilakukan oleh orang perseorangan yaitu aparatur negara atau pejabat publik(Wiyono, 2012, p. 45).

Kewenangan yang dimaksud dalam 
Pasal 3 Undang-Undang Pemberantasan Tipikor merupakan kewenangan dari Pegawai Negeri sebagaimana dimaksud dalam ketentuan Pasal 1 angka 2 huruf a, huruf b, huruf c, huruf d, dan huruf e Undang-Undang Pemberantasan Tipikor, yang pengertiannya lebih luas dari pengertian kewenangan menurut konsep Hukum Tata Negara atau Hukum Tata Usaha Negara yang hanya terbatas pada ketentuan Pasal 1 angka 2 huruf $a$, huruf $b$, huruf $c$, dan huruf e UU Pemberantasan Tipikor.

Secara yuridis, mengenai menyalahgunakan kewenangan karena jabatan, UndangUndang Pemberantasan Tipikor tidak memberikan definisi atau pengertian tersendiri. Istilah "menyalahgunakan kewenangan" justru ditemukan dalam Undang-Undang Administrasi Pemerintahan yaitu sebagai bagian dari Asas-asas Umum Pemerintahan yang Baik (AUPB), diantara berupa "asas tidak menyalahgunakan kewenangan". Dalam penjelasan Pasal 10 ayat (1) huruf e Undang-Undang Nomor 30 Tahun 2014 tentang Administrasi Pemerintahan menyatakan yang dimaksud dengan "asas tidak menyalahgunakan kewenangan" adalah asas yang mewajibkan setiap Badan dan/atau Pejabat Pemerintahan tidak menggunakan kewenangannya untuk kepentingan pribadi atau kepentingan yang lain dan tidak sesuai dengan tujuan pemberian kewenangan tersebut, tidak melampaui, tidak menyalahgunakan, dan/atau tidak mencampuradukkan kewenangan.

\section{Simpulan dan Saran}

1. Simpulan

Dari hasil uraian pembahasan, maka dapat diambil kesimpulan:

1. Diskresi pejabat pemerintahan yang berindikasi adanya penyalahgunaan wewenang, akibat hukumnya diskresi yang diambil oleh pejabat pemerintahan menjadi tidak sah, juga diberikan sanksi kepada pejabat pemerintahan sebagaimana diatur dalam undangundang Nomor 30 Tahun 2014 tentang Administrasi Pemerintahan dan Undang-Undang Nomor 25 Tahun 2009 tentang Pelayanan Publik maupun yang ditentukan dalam peraturan perundang- undangan yang berlaku.

2. Diskresi pejabat pemerintahan yang berindikasi terjadi penyalahgunaan wewenang dapat dipertanggungjawab kan secara pidana, apabila diskresi yang diambil tersebut terjadi perbuatan korupsi yang menimbulkan kerugian negara, pejabat pemerintahan melakukan perbuatan curang, memperkaya diri orang lain, memanipulasi.

\section{Saran}

Kemudian berdasarkan hasil penelitian yang dilakukan, diajukan saran sebagai berikut;

1. Diskresi merupakan tindakan pejabat pemerintahan dalam bertindak untuk kepentingan publik. Perbuatan pejabat pemerintahan yang berindikasi terjadi penyalahgunaan wewenang dalam menerbitkan diskresi, dapat dicegah apabila diskresi yang diambil mengacu pada asas-asas umum pemerintahan yang baik serta Undang-Undang nomor 30 tahun 2014 tentang Administrasi Pemerintahan yang mengatur terkait tujuan penggunaan diskresi.

2. Pertanggungjawaban pidana atas diskresi pejabat pemerintahan dapat dicegah dengan menghindari diri dari tindakan diskresi yang mengandung nuansa hukum pidana, serta memfungsikan fungsi inspektorat sebagai Aparat Pengawas Intern Pemerintah dalam menguji ada tidaknya penyalahgunaan wewenang terhadap diskresi yang diterbitkan pejabat pemerintahan. Perlindungan hukum kepada pejabat pemerintahan dalam mengambil diskresi, diperlukan perubahan terhadap Peraturan Pemerintah Nomor 48 Tahun 2016 tentang tata cara pengenaan sanksi administratif kepada pejabat pemerintahan, untuk mengatur terkait konsekuensi hukum atas Putusan Pengadilan Tata Usaha Negara, serta melakukan perubahan terhadap Peraturan Mahkamah Agung Republik Indonesia Nomor 4 Tahun 2015 tentang Pedoman Beracara Dalam Penilaian Unsur Penyalahgunaan Wewenang, 
yang tidak sejalan dengan UndangUndang Nomor 30 Tahun 2014 tentang Administrasi Pemerintahan.

\section{DAFTAR PUSTAKA}

Ari. (2015). UU Administrasi Pemerintahan Dinilai Mengudeta Pemberantasan Korupsi. Retrieved September 6, 2016, from http://news.detik.com/ berita/2873765/uu-administrasipemerintahan-dinilai-mengudetapemberantasan-korupsi

Azhary. (1995). Negara Hukum Indonesia. Jakarta: UI-Press.

Facruddin, I. (2004). pengawasan peradilan administrasi terhadap tindakan pemerintah. Bandung: Alumni.

Hadjon, P. M. (1997). “Tentang Wewenang”, Yuridika, No. 5 \& 6 Tahun XII, Sep-Des 1997.

Hadjon, P. M. (2015). Peradilan Tata Usaha Negara dalam konteks Undang-Undang No. 30 Tahun 2014 tentang Administrasi Pemerintahan. Jurnal Hukum Dan Peradilan, 4(1).

Kusumohamidjojo, B. (1999). Ketertiban Yang Adil, Problematika Filsafat Hukum. Jakarta: Grasindo.

Latif, A. (2014). Hukum Administrasi Dalam Tindak Pidana Korupsi. Jakarta: Prenada Media Group.

Patiro, Y. M. I. (2012). diskresi pejabat publik dan tindak pidana korupsi. Bandung: Keni Media.

Sahlan, M. (2016). Unsur Menyalahgunakan Kewenangan dalam Tindak Pidana Korupsi sebagai Kompetensi Absolut Peradilan Administrasi.

Jurnal Hukum IUS QUIA IUSTUM, 23(2), 271293 . R e tri e ved from https://media.neliti.com/media/publicat i o n s / 96221 - I D - u n s u r menyalahgunakan-kewenangan-dalamt.pdf

Sinambela, L. P. (2008). Reformasi Pelayanan Publik, Teori, Kebijakan, dan Implementasi. Jakarta: Bumi Aksara.

Syamsudin, A., Ilyas, N., \& Badeoda, Y. B. (2004). SF. Marbu: Analisis Teoritik Yuridik Kasus Akbar Tandjung dari
Optik Hukum Administrasi Negara. J a k a r t a: P u s t a k a $\mathrm{S}$ i n a r Harapan.Widyaningtyas, T. (n.d.). No Title. Retrieved June 4, 2016, from trisnasunawar.blogspot.co.id

Wijayanto. (2009). Korupsi Mengorupsi Indonesia: Sebab, Akibat, dan Prospek Pemberantasan. Jakarta: Gramedia Utama.

Wiyono, R. (2012). Pembahasan UndangUndang Pemberantasan Tindak Pidana Korupsi. Jakarta: Sinar Grafika. 